\title{
São Paulo's strategic master plan and the challenges of sustainable urban transformation
}

\author{
Plano Diretor estratégico de São Paulo e os desafios para a \\ transformação urbana sustentável
}

Adalberto Gregório Back ${ }^{1}$

Gabriela Marques Di Giulio ${ }^{2}$

Tadeu Fabrício Malheiros ${ }^{3}$

${ }^{1}$ PhD in Political Sciences, Researcher, Environmental Health Department, Faculty of Public Health, Universidade de São Paulo (USP), São Paulo, Brazil

E-mail: backgregor@gmail.com

${ }^{2}$ PhD in Environment and Society, Associate Professor, Environmental Health Department, Faculty of Public Health, Universidade de São Paulo (USP), São Paulo, Brazil E-mail:ggiulio@usp.br

${ }^{3}$ PhD in Public Health, Associate Professor, Hydraulics and Sanitation's Department, Engineering School of São Carlos, Universidade de São Paulo (USP), São Carlos, Brazil

E-mail: tmalheiros@usp.br

doi:10.18472/SustDeb.v12n1.2021.40197

\section{ABSTRACT}

Cities play an essential role in the challenge of sustainability, and urban planning is one of the main tools for guiding urban transformation processes. This paper analyses the São Paulo Master Plan 2014, considering the principles and guidelines on compact cities, sustainable adaptation and ecosystembased adaptation. An urban development model within sustainable parameters, however, involves conflict dynamics. In this sense, the views and demands of the main stakeholders seeking to influence the regulatory arena of São Paulo's urban policy are mapped. The analysis focuses on attempts to change the zoning law that would affect several of the definitions agreed in the Master Plan, prioritising mainly the interests of real estate developers.

Palavras-chave: Adaptation. Compact city. Urban planning. Sustainable urban transformation.

\section{RESUMO}

As cidades têm um papel importante no desafio da construção de um modelo de desenvolvimento em parâmetros sustentáveis, sendo o planejamento urbano um dos principais instrumentos para orientar processos de transformação urbana. O presente artigo realiza uma análise sistemática do Plano Diretor de São Paulo 2014 à luz dos princípios e diretrizes sobre cidade compacta, adaptação 
sustentável e adaptação baseada em ecossistemas. Tais instrumentos regulatórios, no entanto, não são isentos de dinâmicas de conflitos. Nesse sentido, mapeiam-se as visões e demandas dos principais atores que buscam exercer influência na arena regulatória da política urbana paulistana analisando-se duas tentativas de alteração extemporânea da Lei de Zoneamento que afetariam várias das definições pactuadas no Plano Diretor, priorizando sobretudo os interesses de incorporadoras imobiliárias.

Keywords: Adaptação. Cidade compacta. Planejamento urbano. Transformação urbana sustentável..

\section{INTRODUCTION}

Cities play a central role in the challenge of an inclusive, safe, resilient, low-carbon and sustainable development model as postulated in international UN agreements, such as the 2030 Agenda for Sustainable Development, New Urban Agenda (Habitat III), Paris Agreement on Climate Change and the Sendai Agreement on Resilient Cities and Disaster Risk Reduction (KLUG, 2018; ROMEROLANKAO et al., 2018; SOTTO et al., 2019).

The challenge for sustainability transitions in cities involves a multiplicity of themes (LOORBACH et al., 2017). In this sense, it is important to differentiate what we mean by sustainable urban development and sustainable urban transformation. In McCormick's definition (2013), sustainable urban development would be sustainable development from a broader perspective that occurs in urban areas' social, economic, environmental and physical dimensions. Sustainable urban transformation, on the other hand, emphasises the development of the urban regions involving changes that occur from governance and planning related to the production and management of urban space, especially transformations in urban design with the potential to generate dynamics of inclusive development, low carbon emissions, safe and resilient. Sustainable urban change, in this sense, is more restricted than the notion of sustainable urban development and involves interventions on the territory (ERNST et al., 2016; MCCORMICK et al., 2013; WAMSLER et al., 2014).

Part of the literature has pointed to guidelines for sustainable urban transformation involving notions such as a compact city (BIANCO et al., 2011; EICHHORST, 2009; EVERS et al., 2018; GEHL, 2013; JACOBS, 2011), sustainable adaptation (CHU et al., 2017; MIRANDOLA et al., 2015; RIBEIRO; SANTOS, 2016; WALNUT; KENNEL, 2017) and ecosystem-based adaptation (BRINK et al., 2016; GENELETTI; ZARDO, 2016; LAFORTEZZA et al., 2013; WAMSLER et al., 2014). This paper analyses the São Paulo Master Plan 2014 (SPMP), considering the main elements that constitute these concepts, particularly the urban morphology and design regulations in city planning (SÃO PAULO, 2014).

However, it is essential to emphasise that sustainable urban transformation implies a normative character, an ideal development model. In this sense, that is an inherently political process involving conflict and agreement dynamics between different stakeholders with different views and interests on urban development (ROMERO-LANKAO et al., 2018; WAMSLER et al., 2013).

The São Paulo Master Plan 2014 (SPMP) brings innovations that aim to change historical paradigms of urbanisation in the city, especially in urban mobility, social housing and environmental sustainability, being a pioneer in the implementation of several urbanistic instruments present in the Statute of Cities $^{1}$ (BONDUKI; ROSSETTO, 2018; FRANCO et al., 2015; LEITE et al., 2015).

One of the most outstanding achievements of the SPMP was the adoption of a set of self-applicable regulatory instruments contributing to the effectiveness in implementing some of its main guidelines. This characteristic is an advance in the Brazilian context. After all, historically, the master plans are marked by being essentially rhetorical and with low effectiveness in implementation, to the 
extent that they rarely present self-applicable regulations and precise definition of the necessary resources, limiting themselves to a programmatic agenda (ULTRAMARI et al., 2015; VILLAÇA, 2005).

The urban instruments and guidelines of municipal master plans can be classified into two dimensions: 1) regulatory arena: rules on occupation and densification of urban areas that limit and restrict the real estate production activity, but also to guide and promote incentives for certain forms of land-use and occupation; 2) redistributive arena: guidelines for State intervention in urban space, functioning as a political agenda for implementation in the medium and long term, but which depends on political will and commitment, as well as the allocation of budgetary resources in the future (LOWI, 1972; VILLAÇA, 2005).

The dynamics of conflicts, interests and agreements between stakeholders occur in different ways in those arenas. On the one hand, in the regulatory arena of urban policy, the stakeholders seek to influence the legal-normative framework that configures urban development policy (Master Plan; Zoning Law; Building Code). On the other hand, in the redistributive arena, the stakeholders seek to influence the distribution of investments in the city, involving the management of urban policy.

The regulatory arena was under pressure for extemporaneous changes in the zoning law between late 2017 and early 2018 (SMUL, 2017) and, later, in the last quarter of 2019 (SMUL, 2019), with proposals that would alter the essence of several devices agreed in the master plan. In the redistributive arena, in turn, several dimensions related to the programmatic guidelines of São Paulo's urban policy defined in the SPMP did not advance as predicted (SÃO PAULO, 2019b).

The São Paulo Master Plan should be in force until 2029 but will be revised in 2021/2022. In this context, it becomes relevant to reflect on the advances and challenges for urban development in São Paulo, given the objectives of sustainable urban transformation. This paper thus seeks to:

19) Identify policies and regulatory instruments provided for in the 2014 SPMP converging with normative guidelines of safe, resilient, low carbon and environmentally sustainable urban development model, according to assumptions found in the theoretical literature.

29) Map the views, interests and demands of the main stakeholders. They seek to influence the regulatory arena of urban policy to identify convergences or distancing from their needs with the objectives of sustainable urban transformation, as defined herein.

\section{METHODOLOGY}

First, from a non-systematized review of the literature on urban governance of climate change, this research provides a synthesis of the main elements that constitute the concepts of a) compact city, b) sustainable adaptation, and c) ecosystem-based adaptation, particularly involving elements related by local governments on land-use and occupation.

In this sense, from a qualitative analysis of São Paulo's Master Plan (SÃO PAULO, 2014), it was possible to identify urban instruments and policies capable of operationalising and implementing the guidelines related to these principles, considering particularly the dimension of urban and environmental policies related to morphology and urban design in the municipality. These instruments and policies were analysed and discussed based on the urban governance literature on climate change, urbanism, and urban policy in the Brazilian and São Paulo contexts.

In addition, this paper identifies and classifies urban policy instruments into two categories: i) regulatory arena: regulations that impose limitations on the individual, without the need for a subsequent regulation for its effectiveness, and ii) programmatic guidelines: attributions to the 
public authorities themselves that require new rules for their effective implementation and, therefore, require political will and subsequent allocation of budgetary resources.

In the regulatory arena, we mapped the main stakeholders that sought to influence the untimely process of revising the zoning law, notably: a) real estate developers, b) middle-class neighbourhood associations present in the expanded centre of the city, and c) social housing movements. To this end, we collected and analysed the drafts of the proposed revision, as well as the drafts of the meetings that debated such proposals in two moments: i) the first attempt took place between December 2017 and February 2018, less than two years after the last revision of the zoning law (SMUL, 2017), and ii) the second attempt took place between October and December 2019 (SMUL, 2019). Regarding the first proposal to amend the law and read the drafts, we analysed the meetings recorded and made available on YouTube. Concerning the second zoning revision proposal, we conduct participant observations in their open meetings, open letters and requests for judicial suspension of the process of amending the zoning law, as well as journalistic material aimed at identifying their positions in the regulatory arena of urban policy. Finally, we collect data produced by private stakeholders such as open letters, requests for judicial suspension of the zoning law revision, and journalistic material focused on identifying their positions in the regulatory arena of urban policy.

Regarding the implementation of the programmatic guidelines, secondary sources were taken as subsidies, such as public authority transparency data available on electronic websites2, in addition to updated academic articles.

\section{COMPACT CITY}

Strategies for achieving a compact urban growth model can be guided by land-use planning through transit-oriented development methodologies that propose territorial principles to be followed: i) compact urban growth with measures that encourage constructive and population density close to the transport axes (CARLTON, 2009); ii) Intensive and mixed use of urban land that brings housing, work, services and leisure closer together, forming interconnected centralities through public transport infrastructure, in order to shorten the distances between home and work and reduce the distances to travel and the dependence on individual motorized transport (JACOBS, 2011), contributing to the reduction of travel by private motor vehicles, and thus reduce local air pollution and GHG emissions (KENNEDY et al., 2009); iii) recapture of the added value generated by real estate valuation in order to promote the redistribution of the benefits obtained, especially by fostering housing of social interest (HSI) in regions with consolidated urban infrastructure and the supply of formal jobs (EVERS et al., 2018); iv) disincentive to individual motorized transport, whether charging fees or limiting garages on public transport axes (EICHHORST, 2009).

In addition to densification and multiple land-uses, the orientation of urban development in a compact way must consider the social inclusion of low-income population with a housing of social interest in areas with a consolidated urban infrastructure. After all, in Brazilian cities, the dynamics that induce urban expansion are related mainly to the housing deficit and the lack of low-income housing options in areas closer to the centre (JENKIS; BURGESS, 2004).

The planning of inclusive, safe and quality transport must take into account a traffic system based on the diversification and connection of transport modes, including non-motorized modes (active mobility as walking or cycling) in addition to the expansion of the high-capacity public transport network, capable of generating higher levels of accessibility and allowing for a reduction in the intensity of travel by individual motorised transport (GEHL, 2013). Furthermore, the diversification and interconnection of modes reduces emissions of pollutants and local GHGs and allows alternative 
routes to respond to extreme weather events, such as heavy rains and floods, which are increasingly frequent and intense, observed in cities (EICHHORST, 2009).

Finally, urban planning aiming at a compact city (Box 1) should consider the urban design that induces greater energy efficiency of buildings. After all, structural aspects of the city related to the built environment can positively or negatively affect the urban energy demand related to the need for heating and cooling of buildings because of the structure, orientation and conditions of buildings and streets in the circulation of winds, insolation and shading, consequently impacting the levels of GHG emissions in a city (BIANCO et al., 2011).

\section{Box 1 | Principles on Compact City}

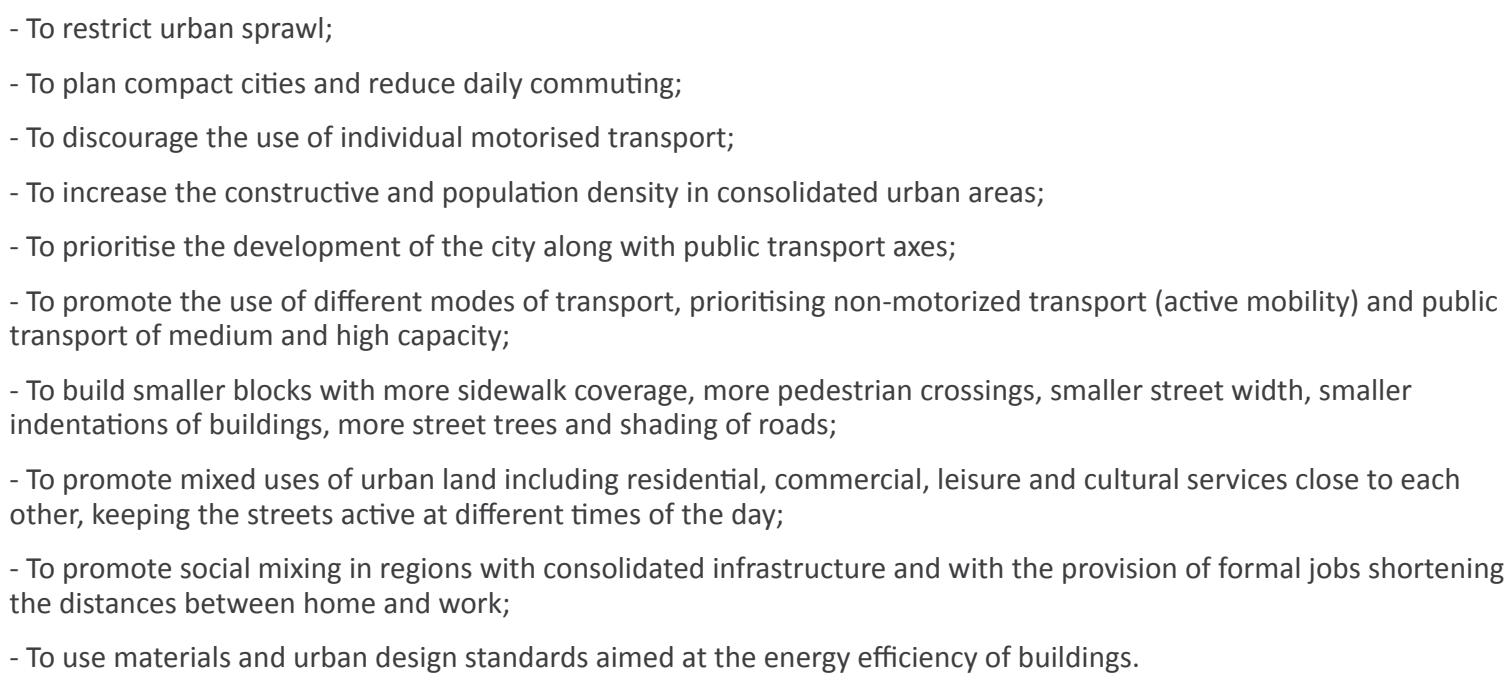

Source: Authors' elaboration.

A set of self-applicable regulatory instruments is present in the SPMP that guide urban development, following the guidelines for designing compact cities. The basis for these innovations is the definition of the coefficient of the essential construction potential equal to the size of the land (CB1) in force throughout the city (BONDUKI; ROSSETTO, 2018; LEITE et al., 2015).

Buildings higher than CB1 require Charges for Additional Building Rights (OODC, acronym in Portuguese) in exchange for more intensive urban land use, only possible with public investments. The application of the OODC provided a substantial increase in extra-budgetary resources for investments in the city, which were previously fully appropriated by real estate producers. Such resources are destined to the Municipal Urban Development Fund (Fundurb), of which at least $30 \%$ should be allocated to the implementation of public transport, cycle and pedestrian traffic systems ${ }^{3}$, as well as another $30 \%$, should be given for the acquisition of land for housing of social interest (HSI), prioritising consolidated urban areas ${ }^{4}$ according to the guidelines defined by the SPMP (FRANCO et al., 2015).

Up to 2014, Fundurb's resources were freely distributed among the secretariats according to political discretion. The master plan, in turn, created sub-bindings of Fundurb's resources to ensure an urban development agenda that prioritised policies for social housing and infrastructure to public transport and active mobility ${ }^{5}$ (PAIM, 2019).

Around the medium and high-capacity public transport axes, called structuring axes of urban transformation, the SPMP defined a set of incentives to promote constructive and population densification, allowing maximum constructive coefficients of 4 times the lot size (CM4). That can be added by $20 \%$ if the active façade (trade and services) is taken on the ground floor of the building 
to link it to the public space and induce the mixed uses of urban land. In addition, progressive discounts are offered in the financial compensation to build above the primary index, the higher the rate of constructive use of buildings in these areas (BONDUKI; ROSSETO, 2018).

To ensure population density, the instrument called maximum quota-part defines that the housing units in the buildings present in the public transport axes have an average of $80 \mathrm{~m} 2$ built area. This leads to diversification in the size of housing units, also contributing to stimulating urban occupations that meet different income ranges.

The SPMP also defined restrictions on the number of garages considered in the urban structuring axes. Thus, up to one garage per residential unit for every $70 \mathrm{~m}^{2}$ of built area in non-residential developments is allowed. Above these limits, garages can be computed as built-up areas and charged for additional building rights in projects located along the structural axes. In this sense, the disincentive to the motorised private car is promoted, mass public transport is encouraged, and the valuable construction space in the urban structuring axes is expanded (LEITE et al., 2015).

Encouraging building density on public transport routes is only possible if, on the other hand, there are restrictions on density throughout the city. In this sense, the master plan determined limitations to density and fertilisation outside the axes of mass public transport. Particularly the mixed and centrality zones have a construction limit of twice the size of the land, building height limits of $28 \mathrm{~m}$ in diverse areas and $48 \mathrm{~m}$ in central areas, restricting real estate production in the core of the uppermiddle-class neighbourhoods (SÃO PAULO, 2014).

Finally, it is necessary to highlight the urban consortium operations (OUC) that aim to encourage and guide the density in urban voids on the railway edge and land of old abandoned factories in central regions with infrastructure. The OUCs need approval in a specific law and may have densification rules higher than the maximum density allowed in the municipality. In urban operations, certificates of additional constructive potential (Cepacs) are bid for raising funds in advance for reinvestment in public works and interventions for the transformation and valuation of real estate in this previously delimited area, with $25 \%$ of the funds collected must be invested in social housing in the surrounding region.

The instrument of urban operations is controversial. On the one hand, it is under the principles of a compact city to promote constructive densification in empty urban areas with infrastructure. However, on the other hand, it concentrates public investments in restricted areas that are already valued in the municipality, to the detriment of investments in the city as a whole, favouring the interests of contractors, real estate developers, private builders and property owners in these regions, whose properties are overvalued in expropriation processes (NOBRE, 2019).

Table 1 systematises the urban instruments of the master plan that aim to operationalise the guidelines and principles related to a compact city model. 
Table 1 | Compact City and the SPMP 2014

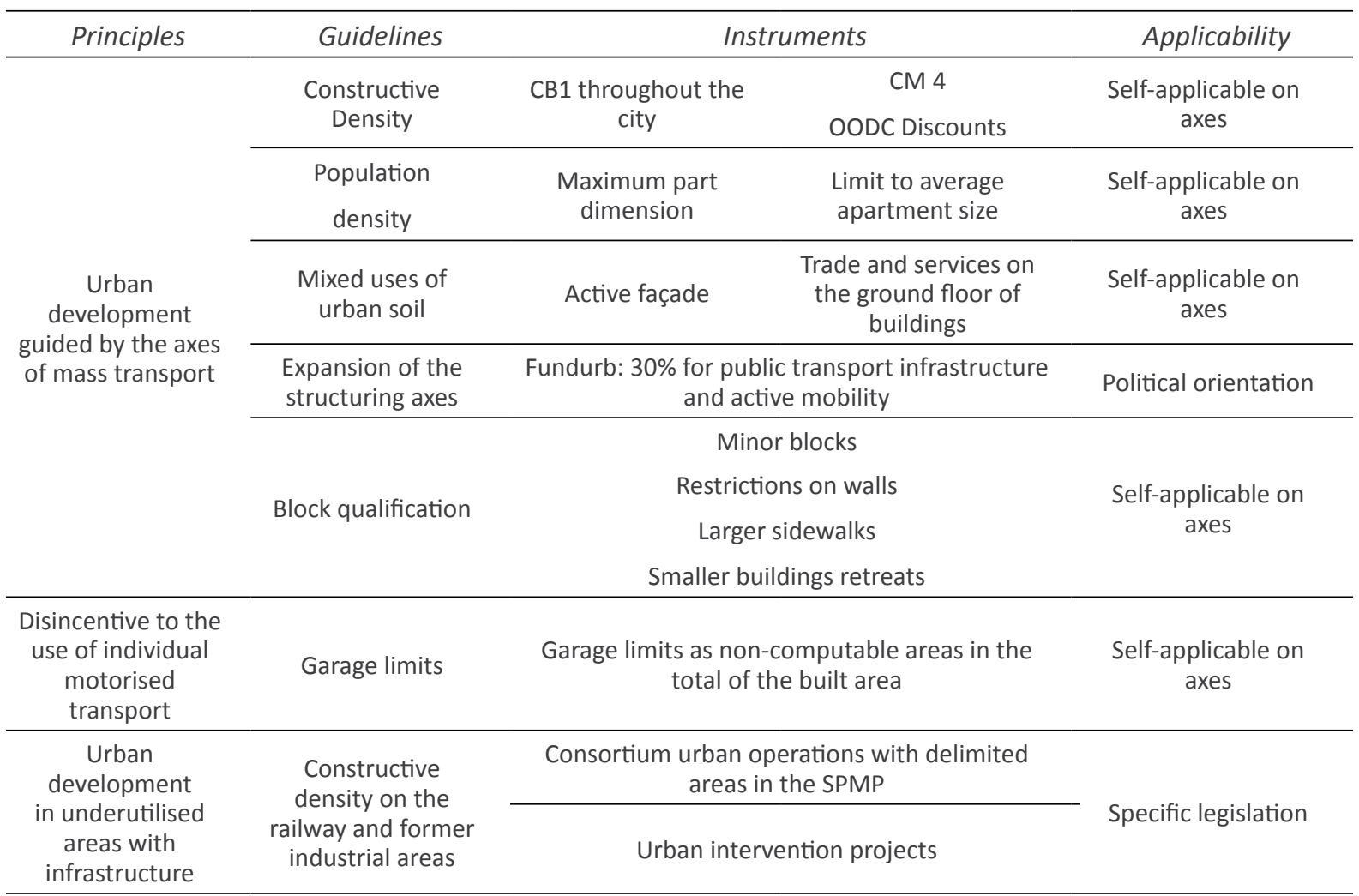

Source: Authors' elaboration.

Most instruments related to the compact city model were defined as self-applicable regulatory instruments. This characteristic gives more excellent stability to the implementation of these guidelines. However, several of these regulations were pressured in the regulatory arena with attempts to change the zoning law in late 2017 and early 2018 and again in November 2019. Notably, in 2017, the principal instruments under pressure from real estate developers and that affect the principles of the compact city are i) discounts on the charges for additional building rights; (ii) greater flexibility in the rules for garages in buildings on public transport routes; iii) extinction of the height limits for buildings in the core of the neighbourhoods (SMUL, 2017).

The demand for discounts on the financial compensation paid for the right to build implies a reduction in Fundurb resources, distributed in investments throughout the city, mainly in social housing and urban mobility. In this sense, the demand of real estate developers goes against the objectives of reducing socio-territorial inequalities, directly affecting the interests of social movements for housing (SMUL, 2018b).

The extinction of height limits in the core of neighbourhoods, in turn, leads to a verticalisation of buildings and, potentially, to a dispersed constructive density in the city, which contradicts the principles of a compact city. In addition, such demand by real estate developers goes against the interests of upper-middle-class neighbourhood associations located in the so-called expanded centre of the city, which have as one of their main demands the maintenance of low-density horizontal neighbourhoods, justified in terms of protecting locality features (SMUL, 2018b). The central region's demand for low construction and population density with consolidated urban infrastructure and high formal jobs also contradicts the compact city principle.

Regarding investments in the city, in 2019, two changes were observed in the criteria defined in the Master Plan for the minimum allocation of Fundurb resources. Firstly, the use of the resource for the 
construction of housing units by the government was allowed, in addition to the restricted use of mere land acquisition, as initially defined. Then, it was possible to use resources in the road system in a broad sense. In the first case, the legislative change corrected a distortion, given that the focus is on ensuring the greater supply of $\mathrm{HSI}$. However, in the second, the change distorts the purpose of investments in active mobility and bus lanes, considering that the resources for these areas start to compete with the road infrastructure works.

The master plan provided for the implementation of $208 \mathrm{~km}$ of bus corridors by 2016, in addition to the current $160 \mathrm{~km}$ preexisting. By 2025 it was expected to implement another $322 \mathrm{~km}$ totalling $690 \mathrm{~km}$ in all. However, only $11.8 \mathrm{~km}$ was implemented up to date, with the most significant delays in lowerincome areas in the east and north of the city (TOMASIELLO et al., 2021). Given that the areas with the highest population density occur in the city's periphery, the difficulty in expanding efficient public transport to these regions highlights the enormous challenge of guiding urban transformation towards a compact city model (SOMEKH; MILITELLI, 2021).

\section{SUSTAINABLE ADAPTATION}

The notion of sustainable adaptation assumes that development must promote both local adaptations to the effects of climate change in the urban context, with measures that contribute to social equity and environmental integrity, two pillars of sustainable development (BROWN, 2011). Adaptation to the effects of climate change is understood as adjustment processes to anticipate impacts and reduce vulnerabilities related to climate variability at the local/regional level (IPCC, 2007).

In this sense, interventions for sustainable adaptation should simultaneously address actions in the short and long term to promote climate risk management and reduce poverty and vulnerabilities (EAKIN et al., 2014).

Thus, risk management is associated with a specific approach to adaptive capacity that considers aspects related to the ability to anticipate, identify and respond to a given risk (AGRAWAL; LEMOS, 2015). On the other hand, the generic adaptive capacity approach is convergent with promoting sustainable development in a perspective that reduces social inequalities and promotes environmental sustainability (BROWN, 2011; DI GIULIO et al., 2016).

Our analysis focuses on the housing policy and risk management policy agreed in the Master Plan, considering the capacity to intervene in urban morphology that promotes the reduction of socioterritorial inequalities in the municipality and the reduction of vulnerabilities and interventions in risk areas (Box 2).

According to the National Civil Defence Policy (2012), the adoption of measures to reduce the risk of disasters is shared among federal entities in the Brazilian context. Still, it is up to the municipalities to identify the risk areas. Thus, municipalities are responsible for the elaboration of geotechnical charters of aptitude for urbanisation that guides the fragilities and potentialities of the territory from its physical characteristics, the processes that generate risk situations and the existing forms of land use and occupation that must be considered in the zoning law to ensure the safety of new land parcels (NOGUEIRA; KENNEL, 2017).

The elaboration of a Municipal Risk Reduction Plan (MRRP) would be a tool capable of managing risks in the city in a systemic and integrated manner. Its objective is to map areas of geological and hydrological risks, define costs of the necessary actions and possible sources of resources to subsidise environmental recovery programs, land regularisation measures, structural activities and eventual reallocations of populations in risk areas (MIRANDOLA et al., 2015). 
Land regularisation and the housing supply of social interest focused on the lower-income groups of the population in urbanised areas are converging measures to reduce socio-territorial inequalities and contain urban sprawl. However, the feasibility of housing projects faces financial barriers to its effective implementation, and it is essential to consider the existence of institutional mechanisms that guarantee regular resources focused on housing (RIBEIRO; SANTOS, 2016).

\section{Box 2 Principles for increasing adaptive capacity and urban resilience}

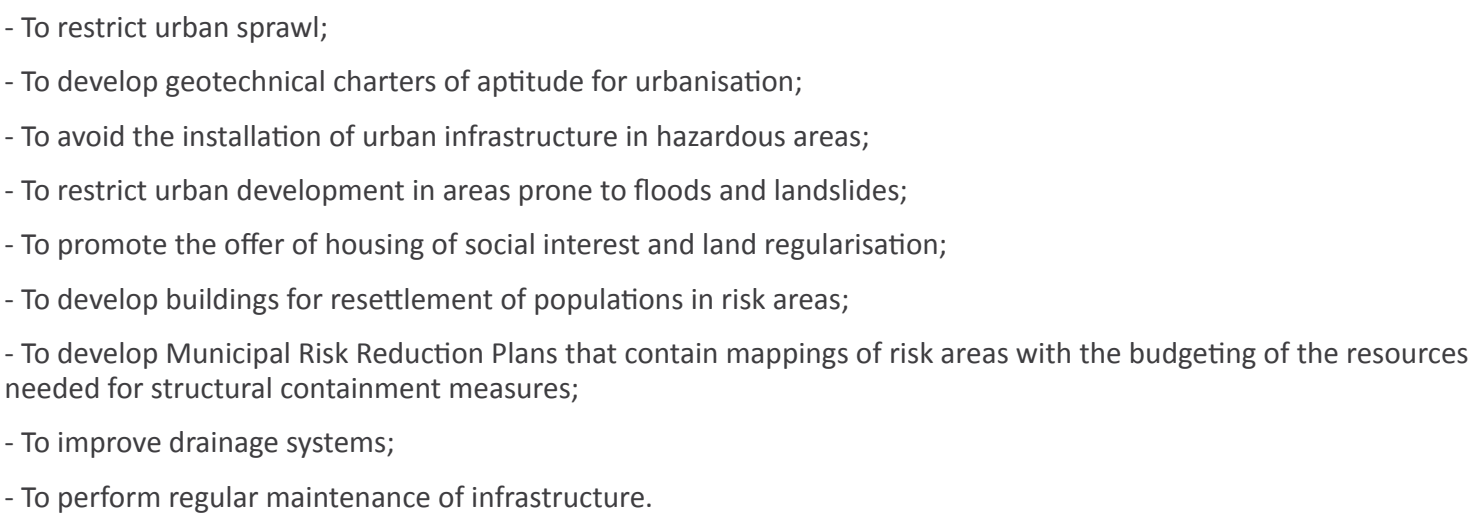

Source: Authors' elaboration.

The 2014 Master Plan regulates a set of instruments to promote the reduction of socio-territorial urban inequalities while reducing vulnerabilities and improving socio-environmental risk management. In this sense, it stands out: i) the provision of regular resources for housings of social interest; ii) the reservation of land in consolidated urban areas to provide housing for the low-income population; iii) urban instruments to curb the idleness of urban real estate and give social function to the property; iv) the urbanisation of slums, land regularisation of precarious urban settlements and resettlement of people living in risk areas and environmental preservation areas.

The funds raised from the charges for additional building rights are destined to the Municipal Urban Development Fund (Fundurb), of which $30 \%$ must be allocated to housing of social interest (HSI) and provide regular extrabudgetary resources for investment in the municipality, aiming at the redistribution of urban capital gains (FRANCO et al., 2015). In the urban consortium operations, in turn, $25 \%$ of the amounts collected should be allocated to HSI in precarious settlements around them. In the latter case, however, the amounts collected remain concentrated in a specific region of the city (NOBRE, 2019).

The solidarity quota, in turn, is an urban instrument that determines that large real estate projects (above $20,000 \mathrm{~m} 2$ ) must produce $\mathrm{HSI}$ or donate resources equivalent to $10 \%$ of the area of their enterprise to HSI (ALBUQUERQUE et al., 2015).

In addition to the provision of regular resources for housing, the 2014 master plan expanded the delimitation of special areas of social interest (ZEIS, acronym in Portuguese), involving: i) land regularisation and urbanisation of slums (ZEIS 1); ii) housing supply in urban voids (ZEIS 2); iii) production and renovation of housing on underutilised land or properties in areas with consolidated urban infrastructure, services and formal jobs, generally located in the central region of the city (ZEIS 3); iv) production of HSI in watershed protection areas, which are endowed with previous urban infrastructure, aimed exclusively at the population transferred from risk areas and the margins of dams (ZEIS 4); and v) housing supply to a middle class in urban voids close to the central region of the city (ZEIS 5). 
In all ZEIS, the constructive densification allowed is equivalent to 4 times the lot size. In ZEIS 1, 2, 3 and 4 , the government and private developers must offer as a rule at least $60 \%$ of the housing units of the building for income range up to 3 minimum wages (HSI 1). The remaining housing units can be offered according to the following parameters: $20 \%$ more for HSI 1 (up to 3 minimum wages) or HSI 2 (3 to 6 minimum wages) and the remaining $20 \%$ for the popular housing market (PHM), aimed at the public with an income of 6 to 10 minimum wages. This was an important advance in the 2014 SPMP related to the demand for social movements for housing and aims to meet the higher demand for housing concentrated in the lower-income layers.

However, the areas classified as ZEIS 5 apply different rules for the supply of housing units per income range, meeting the demand of real estate sectors that operate in this segment and that pressed for a higher percentage of destination for the public with income between 6 to 10 minimum wages. In ZEIS 5, therefore, $40 \%$ can be allocated to HSI 1 or HSI 2, and up to $60 \%$ can be allocated to PHM (BONDUKI, 2018).

Concerning the instruments that aim to give social function to the property and curb the idleness of urban real estate, since 2010, São Paulo has legislation that regulates the instrument of Parcelling and Building Compulsory (PEUC, acronym in Portuguese) and its derivatives: Progressive urban property tax over time (IPTU, acronym in Portuguese) and Expropriation with payment insecurities. However, its application was flawed, not generating legal obligations to notify owners. The 2014 master plan established precise rules. It expanded the areas that could be used for implementing the PEUC in qualified areas of the city, including ZEIS 2, 3 and 5, in consortium urban operations areas, Sé and Mooca subprefectures, areas of influence of the axes of structuring urban transformation, urbanised areas, as well as glebes larger than $20,000 \mathrm{~m} 2$ in peripheral areas of the city (BONDUKI; ROSSETTO, 2018).

Concerning the measures that contribute to risk reduction and management, it is worth highlighting the geotechnical charter of aptitude for urbanisation and the municipal risk reduction plan. The geotechnical charter prevents formal constructions in areas prone to geological risk at the time of the construction permit. Despite being an important planning and information tool, the geotechnical charter does not regulate the formal occupations, which are most dwellings in risk areas in the municipality.

The Municipal Risk Reduction Plan was foreseen in the Master Plan as an instrument that should be elaborated identifying vulnerable areas and populations to geological and hydrological risks, budget estimates on the resources needed with structural actions (such as slope containment, for example) and/or relocation of populations at risk to reduce vulnerabilities and address the risks in the city in an integrated and systemic way. However, seven years after the publication of the SPMP, little progress has been made in developing this vital planning and risk management tool in the city.

Table 2 systematises the main instruments present in the SPMP converging with the guidelines of an urban development model to reduce socio-territorial inequalities and vulnerabilities. 
Table 2 | Sustainable adaptation

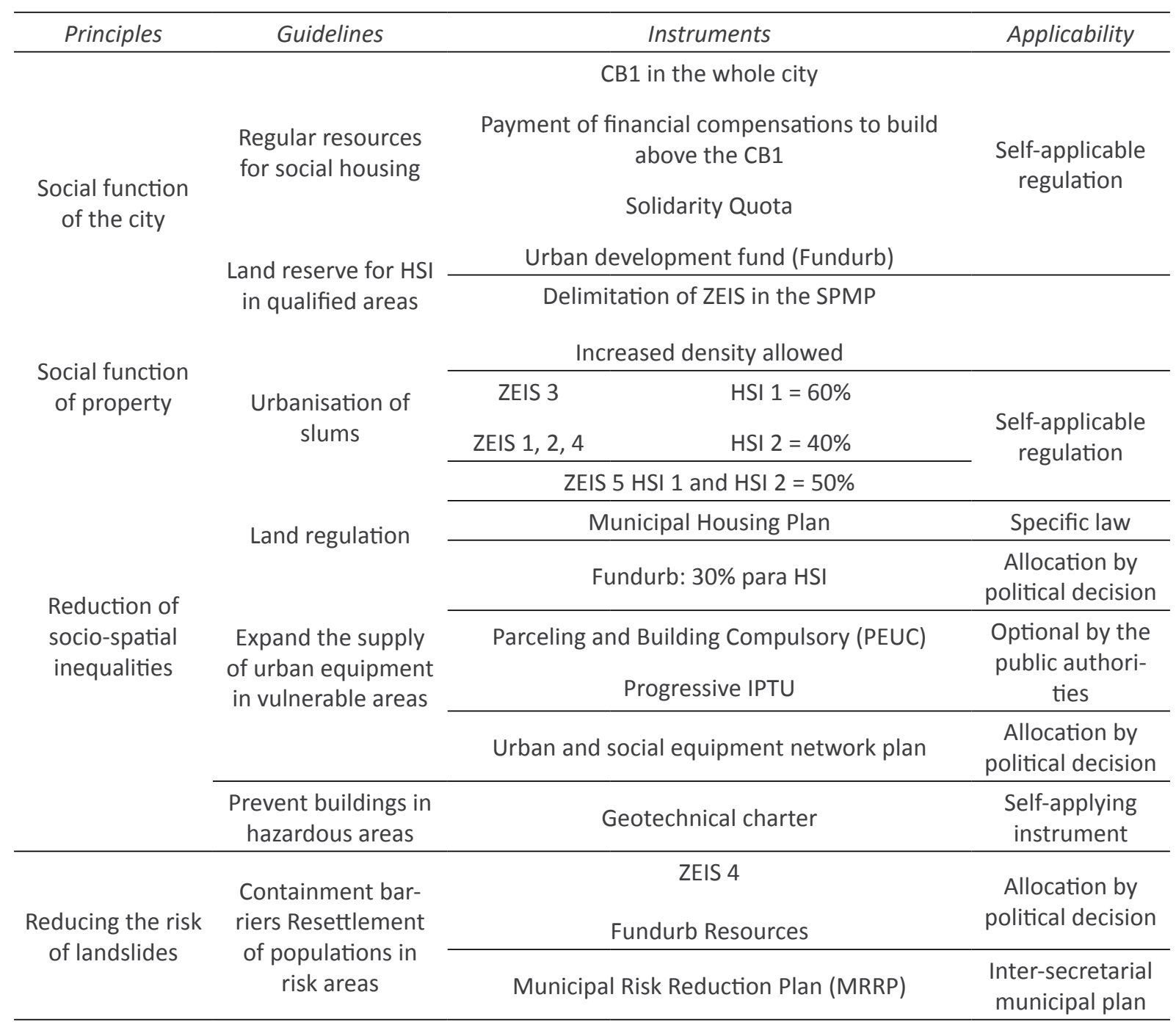

Source: Authors' elaboration.

As mentioned earlier, the regulatory arena of urban policy was the subject of pressure from real estate developers in late 2017, less than two years after the last revision of the zoning law. Among their main demands that would influence the principles of sustainable adaptation involving the reduction of socio-territorial inequalities, the following stand out: i) reduction in the amounts of financial compensation paid for the right to build; ii) elimination of the solidarity quota that obliges sizeable real estate developments to produce or donate resources housing of social interest, in percentage terms to their project; iii) reduction of the mandatory percentage of supply of housing units for low income, from the current minimum of $60 \%$ for a pairing ( $50 \%$ and $50 \%$ ) of the proportion of the supply of HSI 1 and other modalities aimed at higher income groups (SMUL, 2017).

These demands to change regulatory instruments meet the interests of increased profitability by real estate developers. However, they would have the consequence of reducing the resources distributed throughout the city, especially for social housing. Moreover, if such demands were implemented, it would reduce HSI supply to the lower-income groups, directly contradicting the demands of social movements for housing.

The strong opposition undertaken by both associations of upper-middle-class neighbourhoods and social movements for housing has succeeded in suspending the process of extemporaneous revision of 
the zoning law. That opposition was expressed from mobilisations in public consultation meetings, the preparation of an open letter to the mayor and the subscription of a judicial petition to suspend the process of reviewing the legislation that ran counter to their interests, alleging non-compliance with the formal rites for the processing of the law (SMUL, 2018a).

In November 2019, in a new attempt to revise the zoning law, there was a retreat concerning the discount on the charge for additional building rights (OODC) and solidarity quota. In addition, the government proposed to mediate solutions to these conflicting demands. It indicated that solidarity quota could be voluntary for undertakings smaller than $500 \mathrm{~m} 2$ with the counterpart of gains in productive potential; ii) and maintained the initial ratio of $60 \% \mathrm{HSI} 1$ and $40 \%$ other modalities, however allowing a higher rate of constructive use in ZEIS without OODC since $20 \%$ of the HSI (additional) were aimed at the ranges up to 3 minimum wages (SMUL, 2019).

\section{ECOSYSTEM-BASED ADAPTATION}

The guidelines for ecosystem-based adaptation are related to initiatives in green infrastructure, distributed in the municipality, which generate environmental, social, economic co-benefits and the promotion of well-being and health while providing improvement in urban drainage, reduction of geological vulnerabilities to climate extreme events and reduction of heat islands in the urban fabric. In addition, such initiatives contribute to promoting the control of urban sprawl, protecting waterproducing springs and ecosystems with green belts in the outskirts of the city, as well as promoting urban and peri-urban agriculture (BRINK et al., 2016; GENELETTI; ZARDO, 2016; LAFORTEZZA et al., 2013; WAMSLER et al., 2014).

The adaptation challenges of Brazilian cities can be faced with lower financial costs and more significant environmental gains. This is reachable by implementing green infrastructure solutions that allow the structuring of alternative drainage systems, combining low-impact solutions such as urban green corridors, hillside reforestation and green streets rather than conventional engineering measures (grey infrastructure) (HERZOG; ROSA, 2010).

Urban parks distributed in several neighbourhoods throughout the city, linear parks on the banks of streams, afforestation of streets and avenues and incentives to promote green spaces in private real estate developments are measures that contribute to: i) reducing soil waterproofing and the potential for flooding, ii) promoting microclimatic cooling and reduce the heat island effect, iii) reducing noise pollution and iv) qualify the urban landscape, performing multiple functions: ecological, aesthetic, educational, sociability and leisure (JACOBI et al., 2015; LAFORTEZZA et al., 2013).

In turn, the conservation and restoration of green belts in the peripheral areas of the city with urban forests and the incentive to urban and peri-urban agricultural production are initiatives that simultaneously contribute to protecting and preserving watershed areas, contain urban sprawl and promote livelihoods for local communities, tourism opportunities and food security (BRINK et al., 2016; CHU et al., 2017). 


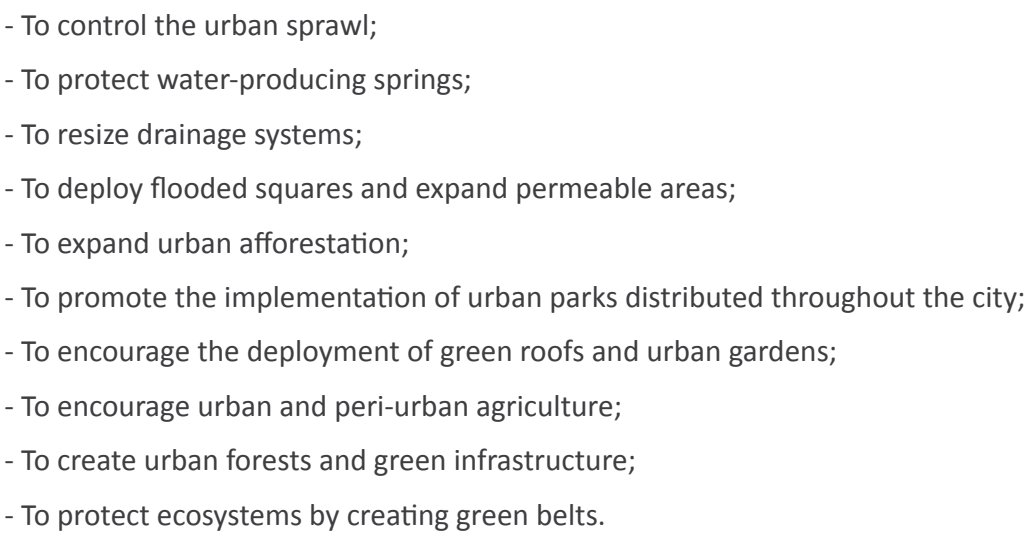

Source: Authors' elaboration.

The 2014 Master Plan recognises special treatment for the management, conservation and restoration of green areas in the text of the law. Among the main points of the environmental sustainability agenda and the containment of urban sprawl in the master plan, it is worth highlighting the delimitation of rural areas in the municipality, incentives for organic agriculture, ecotourism and payment for environmental services (FRANCO et al., 2015).

With these measures, the master plan aims to simultaneously promote sustainable agriculture in the city's green belt through expanding the offer of agroecological products, generating and maintaining jobs in the rural area, avoiding population evasion in the region; hindering the advancement of irregular occupations by maintaining the rural character in the region; and preserving the springs contributing to the quality of the surrounding springs, especially in the south of São Paulo. Thus, it is moving towards qualifying the use-value in environmental protection areas to contain urban expansion, not simply restricting urban use but mainly encouraging sustainable use in these areas (NAKAMURA; MARK, 2021).

In the urban space, among some main proposals of environmental qualification, we highlight the delimitation made in the master plan of areas for parks creation distributed by the municipality, the forecast for the creation of a specific fund for the implementation and management of parks, as well as the plan of afforestation of the city.

The master plan demarcated 167 areas (public and private) for the implementation of parks (urban and natural) in addition to the 121 existing parks at the time. The demarcation of these areas as special environmental protection zones (ZEPAM, acronym in Portuguese) restricts the constructive use by making formal real estate projects in these areas unfeasible. On the other hand, their owners can receive resources from the payment mechanism for environmental services or transfer them to the municipality, receiving monetary values in exchange (BONDUKI, 2014).

The so-called environmental quota is another relevant mechanism that accompanies the set of urban and environmental law innovations in the city. It is an urban regulatory instrument that establishes rules for an environmental qualification within the scope of the lot for new buildings from $500 \mathrm{~m} 2$ of the area in some areas of the municipality, as defined by the zoning law of the municipality (LPUOS, acronym in Portuguese) (SÃO PAULO, 2016).

The main objective of the environmental quota is to promote the creation of green spaces in construction projects in some areas of the city, aiming at increasing soil permeability and increasing vegetation cover within the lot to reduce the effects of heat island and provide better drainage of rainwater, contributing to minimise effects of flooding in the city (CAETANO, 2016; MALERONKA, 2015). 
Table 3 highlights the main instruments, policies and guidelines present in the SPMP associated with the urban development model based on the principles of ecosystem-based adaptation.

Table 3 | Ecosystem-based adaptation

\begin{tabular}{|c|c|c|c|}
\hline Principles & Guidelines & Instruments & Applicability \\
\hline \multirow[b]{3}{*}{$\begin{array}{l}\text { Creation of green belts on } \\
\text { the outskirts of the city }\end{array}$} & \multirow{2}{*}{$\begin{array}{l}\text { Encourage urban and peri- } \\
\text { urban agriculture }\end{array}$} & $\begin{array}{l}\text { Delimitation of rural area } \\
\text { in zoning }\end{array}$ & Self-applicable regulation \\
\hline & & $\begin{array}{l}\text { Sustainable rural } \\
\text { development plan }\end{array}$ & Programmatic Guideline \\
\hline & $\begin{array}{l}\text { Delimiting areas providing } \\
\text { environmental services }\end{array}$ & $\begin{array}{l}\text { Payment of environmental } \\
\text { services (bids) }\end{array}$ & Programmatic Guideline \\
\hline $\begin{array}{l}\text { Protection of water- } \\
\text { producing springs }\end{array}$ & Preserving urban forests & $\begin{array}{c}\text { Municipal Plan for } \\
\text { conservation and recovery } \\
\text { of the Atlantic Forest }\end{array}$ & $\begin{array}{l}\text { Programmatic } \\
\text { Guideline }\end{array}$ \\
\hline \multirow{3}{*}{ Flood risk reduction } & \multirow{3}{*}{$\begin{array}{l}\text { Expand flooded areas and } \\
\text { permeable areas }\end{array}$} & Environmental quota & $\begin{array}{l}\text { Self-applicable regulation } \\
\text { (LPUOS) }\end{array}$ \\
\hline & & $\begin{array}{l}\text { Delimitation of areas } \\
\text { for the creation of parks } \\
\text { distributed throughout } \\
\text { the city }\end{array}$ & $\begin{array}{l}\text { Limitations in the master } \\
\text { plan }\end{array}$ \\
\hline & & $\begin{array}{l}\text { Resources for creating } \\
\text { parks }\end{array}$ & Fundurb and Specific Fund \\
\hline Reduction of heat islands & Urban afforestation & $\begin{array}{l}\text { Urban Afforestation } \\
\text { Municipal Plan }\end{array}$ & Programmatic Guideline \\
\hline
\end{tabular}

Source: Authors' elaboration.

The recognition of São Paulo's rural areas in the master plan has generated possibilities for farmers to access rural credit and markets for agroecological products, besides being a measure to contain urban expansion and maintain green areas (NAKAMURA; MARCOS, 2021). Likewise, the Payment for Environmental Services instrument proposed by the master plan contributes to the preservation and environmental recovery of ecosystems, particularly the protection of water sources (SEPE; PEREIRA, 2015).

However, the municipal environmental policy defined by the Master Plan is composed mainly of programmatic guidelines and, therefore, its practical implementation is dependent on political will and allocation of resources, especially the resources of the municipal secretary of green and environment, which are in dispute with other secretariats (DI GIULIO, 2020). In this context, the environmental policy provided for in the Master Plan was the one that has made minor progress since the enactment of the 
SPMP, with the low implementation of new parks (SÃO PAULO, 2019b) and the observation of urban expansion at the expense of illegal deforestation in peri-urban forests (NATALINI, 2020).

Concerning the regulatory arena, the environmental quota was subject to an attempt to change in 2018, changing the scope of the instrument from $500 \mathrm{~m} 2$ to $1,000 \mathrm{~m} 2$ (SMUL, 2017). This proposal is based on a demand of real estate producers aiming to reduce costs and expand the constructive use. However, it would result in a decrease in the number of new buildings with incentives to adopt sustainable construction procedures, which would result in a reduction in the adaptative capacity and an increase in heat islands. In other words, the private interest in maximising profit by real estate producers would negatively affect the public interest. In 2019, there were setbacks in this proposal, but it allowed greater flexibility of the instrument involving other forms of environmental qualification (SMUL, 2019).

\section{CONCLUDING REMARKS}

The paper aimed to map regulatory instruments of urban policy capable of operationalising the objectives of an urban transformation towards a compact city model, which aims to reduce socioterritorial inequalities, increase resilience and environmental qualification. In this context, it was observed that the sociopolitical pact defined by the São Paulo Master Plan brought some innovations converging with these principles and guidelines.

One of the significant advances of the master plan is the self-applicable regulatory instruments in the axes of medium and high-capacity public transport for guidance aimed at the principles of a compact city. In addition, there was an increase in extrabudgetary resources for investments in the city, particularly in social housing and urban mobility.

However, in the two administrations that followed the SPMP approval, the regulatory arena was subjected to pressure from real estate producers who sought to relax regulations that would negatively affect the objectives of a compact city, related to environmental qualification and reduction socioterritorial inequities.

Among the main demands of real estate developers in the regulatory arena that would affect the objectives of a compact city, the following stand out: i) discounts on financial compensations paid for the right to build above the primary index; (ii) elimination of limits to the verticalisation of buildings in the inner core of neighbourhoods; iii) flexibilisation of computable garages as a built-up area in new buildings along public transport routes.

Regarding the demands of real estate developers that would negatively affect the objectives of reducing socio-territorial inequities and improving urban resilience, the following stand out: i) discounts on the charge for additional building rights, which would reduce resources for investments in a comprehensive manner in the city, including resources for social housing and population relocation in risk areas; ii) reduction in the mandatory percentage of supply of low-income housing units in ZEIS.

Finally, concerning the regulatory instruments of urban policy associated with an environmental qualification in new buildings, real estate developers pressed for their application to cease being mandatory for buildings smaller than $1,000 \mathrm{~m}^{2}$, making the instrument's objectives unfeasible.

However, such proposals to change the zoning law were blocked by a coalition involving middleclass neighbourhood associations and social housing movements that saw setbacks in the sociopolitical pact established in the Master Plan and would affect their interests and views on urban development differently. 
It is also worth mentioning that the Executive Power in 2019 was the guarantor of two amendments to the Master Plan on how Fundurb resources are used: i) it allowed the resources to be also used to offer social housing, in addition to the mere acquisition of land, as initially planned, correcting a distortion; ii) and it enabled the resources for urban mobility to be used unrestrictedly in infrastructure, distorting the initial purpose of complete application in infrastructure for public transport and active mobility that would need to be prioritised, especially in peripheral regions, following the objectives of interconnected cities with low carbon emissions and more energy-efficient transport.

The environmental and disaster risk reduction agendas, both more directly related to the objectives of a safe, resilient and sustainable city model, were the ones that advanced made minor progress during this period. Although there are several forecasts in the Master Plan on these agendas, most of the law's provisions are fundamentally programmatic guidelines and, in that condition, are susceptible to political commitment and allocation of resources in the future time.

In summary, the socio-political pact defined by the 2014 master plan is not stable, and during the two administrations following its approval, some pressures concurred to mischaracterise its objectives, prioritising, above all, the interests of real estate developers.

Despite the peculiarities of São Paulo's city, such as its diversified and prosperous real estate market, historically organised and active social housing movements and an upper-middle-class elite established in the expanded centre with demands for low population and construction densities, the research results presented here can serve as a reference to inspire studies on the challenges for sustainable transformation in other urban contexts.

\section{NOTES}

1 | Federal Law 10, 257 of July 10, 2001, establishes general urban policy guidelines and provides other measures.

2 | Available in: https://www.prefeitura.sp.gov.br/cidade/secretarias/licenciamento/desenvolvimento_urbano/ dados_estatisticos/Accessed on: 16 October 2020.

3 | Item II of Art. 340 of the São Paulo Master Plan (SÃO PAULO, 2014).

4 | Item I of Art. 340 of the São Paulo Master Plan (SÃO PAULO, 2014).

5 | These rules of application of Fundurb resources have undergone major changes given by law 17,217 of October 23, 2019, as will be discussed later.

\section{ACKNOWLEDGEMENTS}

Thanks to Fapesp - State of São Paulo Research Foundation - for the fundamental financial support for this research, Process no 2019/02914-6 and Process no 2017/50423-6.

\section{REFERENCES}

AGRAWAL, A.; LEMOS, M. C. Adaptative development. Nature Climate Change, v. 5, p. 185-7, 2015.

ALBUQUeRQUE, G. H. B.; COSTA, A. B. P. P.; RAMPAZIO, L. P. Cota de solidariedade: comparando políticas entre cidades Norte-Americanas e São Paulo. PARC - Pesquisa em Arquitetura e Construção, Campinas, SP, v. 6, n. 1, p. 56-68, 2015.

BIANCO, H. et al. The role of urban land in climate change. In: ROSENZWEIG, C. et. al. Climate change and cities: first assessment report of the urban climate change research network. New York: Cambridge University Press, p. 217-248, 2011. 
BONDUKI, N. Os avanços ambientais do Plano Diretor. Carta Capital, 05 jun. 2014. Available in: http://www.cartacapital. com.br/sociedade/os-avancos-ambientais-do-plano-diretor-3453.html. Access on: 04 jul. 2019.

BONDUKI, N.; ROSSETO, R. A reforma urbana no Plano Diretor Estratégico de São Paulo de 2002 e 2014. In.: BONDUKI, N. (Org.) A luta pela reforma urbana no Brasil: do seminário de habitação e reforma urbana ao Plano Diretor de São Paulo. São Paulo: Instituto Casa da Cidade, 2018.

BRAGA, R. Mudanças climáticas e planejamento urbano: uma análise do Estatuto da Cidade. In: VI ENCONTRO NACIONAL DA ANPPAS, 2012.

BRINK, E. et al. Cascades of green: a review of ecosystem-based adaptation in urban areas. Global Environmental Change, v. 36, p. 111-123, 2016

BROWN, K. Sustainable Adaptation: and oxymoron? Climate and Development, v. 3, p. 21-31, 2011.

BULKELEY, H.; BETSILL, M. Revisiting the urban politics of climate change. Environmental Politics, Cambridge, v. 22, n. 1, p. 136-154, 2013.

CAETANO, P. M. D. Fundamentação teórica da Quota Ambiental e estudo de caso de seu desenvolvimento em São Paulo. Tese (Doutorado em Saúde Pública) - Faculdade de Saúde Pública, Universidade de São Paulo, 2016.

CARLTON, I. Histories of Transit Oriented Development: perspectives on the development of the TOD Concept. Institute of urban and regional development. Berkeley: Working Paper, 2009.

CHU, E. et al. Climate adaptation as strategic urbanism: assessing opportunities and uncertainties for equity and inclusive development in cities. Cities, v. 60, p. 378-387, 2017.

DI GIULIO, G. M. et al. Bridging the gap between will and action on climate change adaptation in large cities in Brazil. Regional Environmental Change, v. 19, p. 2491-2502, 2019.

DI GIULIO, G. M.; MARTINS, A. M. B.; LEMOS, M. C. Adaptação climática: fronteiras do conhecimento para pensar o contexto brasileiro. Estudos Avançados, v. 30, n. 88, p. 25-40, 2016.

EAKIN, H.; LEMOS, M. C.; NELSON, D. Differentiating capacities as a mean to sustainable climate change adaptation. Global Environmental Change, v. 27, p. 1-8, 2014.

EICHHORST, U. Adapting Urban Transport to Climate Change. A Sourcebook for policy-makers in developing cities. Eschborn, 2009.

ERNST, L. et al. Sustainable urban transformation and sustainability transitions: conceptual framework and case study. Journal of Cleaner Production, n. 112, p. 2988-2999, 2016.

EVERS, H. et al. Dots nos Planos Diretores: guia para inclusão do Desenvolvimento Orientado ao Transporte Sustentável no Planejamento Urbano. 2018.

FRANCO, F. M.; D’ALMEIDA, C. H.; ABREU, G. K. M. A Macroárea de Estruturação Metropolitana de São Paulo: o projeto urbano como instrumento de transformação do território. Revista Iberoamericana de Urbanismo, ano 7, n. 12, p. 52-74, dez. 2015.

GEHL, J. Cidades para pessoas. 2. ed. São Paulo: Editora Pesrpectiva S.A., 2013.

GENELETTI, D.; ZARDO, L. Ecosystem-based adaptation in cities: an analysis of European urban climate adaptation plans. Land use Policy, v. 50, p. 38-47, 2016.

HERZOG, C.; ROSA, L. Infraestrutura Verde: sustentabilidade e resiliência para a paisagem urbana. Revista LABVERDE, n. 1, p. 92-115, 2010. 
INTERGOVERNMENTAL PANEL ON CLIMATE CHANGE [IPCC]. Climate Change 2007: synthesis report. In: PACHAURI, R. K.; REISINGER, A. (Ed.). Contribution of Working Groups I, II and III to the Fourth Assessment Report of the Intergovernmental Panel on Climate Change, Cambridge Unternakiversity Press, Cambridge, 2007.

JACOBI, P. R.; FRACALANZA, A. P.; SILVA-SÁNCHEZ, S. Governança da água e inovação na política de recuperação de recursos hídricos na cidade de São Paulo. Cadernos Metropolis. [on-line], v. 17, n. 33, p. 61-81, 2015.

JACOBS, J. Morte e Vidas de Grandes Cidades. 3. ed. São Paulo: Editora WMF Martins Fontes, 2011.

JENKIS, M.; BURGESS, R. Compact Cities: sustainable urban forms for developing countries. Routledge Press, 2001.

JIANG, Y. et al. A review of urban planning research for climate change. Sustainability Review. 2 december 2017.

KENNEDY, C. A. et al. Greenhouse Gas Emission Baselines for Global Cities and Metropolitan Regions. Work Bank, 2009.

KLUG, L. Resiliência e ecologia urbana. In: COSTA, M. A.; THADEU, M.; FAVARÃO, C. (Org.). A nova agenda urbana e o Brasil: insumos para sua construção e desafios para a sua implementação, Ipea, 2018.

LAFORTEZZA, R. et al. Green Infrastructure as a tool to support spatial planning in European urban regions. iFor. Biogeosci. For., v. 6, p. 102-108, 2013.

LEITE, C.; LONGO, M.; GUERRA, M. Redes de centralidades multifuncionais e de compacidade urbana na reestruturação territorial de São Paulo. Revista Iberoamericana de Urbanismo, ano 7, n. 12, p. 93-120. dez. 2015.

LOORBACH, D.; FRANTZESKAKI, N.; AVELINO, F. Sustainability Transitions Research: transforming science and practice for societal change. Annual Review of Environment and Resources, v. 42, n. 1, p. 599-626, 2017.

LOWI, T. Four systems of policy, politics, and choice. Public Administration Review, v. 32, n. 4, p. 298-310, 1972.

MALERONKA, C. Intervenção urbana e financiamento: a experiência de São Paulo na recuperação de mais-valias fundiárias. Revista Iberoamericana de Urbanismo, ano 7, n. 12. p. 75-92, dez. 2015.

MCCORMICK, K. et al. Advancing sustainable urban transformation. Journal of Cleaner Production, n. 50, p. 1-11, 2013.

MIRANDOLA, F. A.; NOGUEIRA, F. R.; MACEDO, E. S. O PMRR (Plano Municipal de Redução de Riscos) como instrumento na Gestão Regional de Riscos Urbanos: o exemplo da região do $A B C$ paulista. $15^{\circ}$ Congresso Brasileiro de Geologia de Engenharia e Ambiental, 2015.

NAKAMURA, A. C.; MARCOS, V. Agricultura urbana e agroecologia no território do extremo sul do município de São Paulo. Agricultura urbana. Estudos Avançados, v. 35, n. 101, jan-abril, 2021.

NATALINI, G. A Devastação da Mata Atlântica no Município de São Paulo. 2. ed., Abr. 2020.

NOBRE, E. A. C. Do Plano Diretor às operações urbanas consorciadas: a ascensão do discurso neoliberal e dos grandes projetos urbanos no planejamento paulistano. São Paulo: Annablume, v. 1, 2019, 344p.

NOGUEIRA, F. R.; CANIL, K. Cartas Geotécnicas de Aptidão à Urbanização: instrumento de prevenção de desastres e para a gestão do uso do solo. Sessão Temática 8: Técnicas e Métodos para Análise Urbana e Regional Resumo, p. 1-15, 2017.

PAIM, D. G. A instrumentalização da política urbana no município de São Paulo: uma análise do Fundo de Desenvolvimento Urbano, 2019. Dissertação (Mestrado em Gestão de Políticas Públicas) - Escola de Artes, Ciências e Humanidades da Universidade de São Paulo, 2019.

RIBEIRO, S. K.; SANTOS, A. S. Mudanças Climáticas e Cidades: relatório especial do Painel Brasileiro de Mudanças Climáticas. Rio de Janeiro, 2016.

ROMERO-LANKAO, et al. Urban transformative potential in a changing climate. Nature Climate Change 8, 2018, p. 754-756. 
SÃO PAULO (Município). Lei no 16.050, de 31 de julho de 2014. Aprova a Política de Desenvolvimento Urbano e o Plano Diretor Estratégico do Município de São Paulo e revoga a Lei no 13.430/2002, 2014.

SÃO PAULO (Município). Lei no 16.402, de 22 de março de 2016. Disciplina o parcelamento, o uso e a ocupação do solo no município de São Paulo, de acordo com a Lei no 16.050, de 31 de julho de 2014 - Plano Diretor Estratégico (PDE). Secretaria do Governo Municipal, em 22 de março de 2016.

SÃO PAULO (Município). Revoga parcialmente planos de melhoramentos viários aprovados pelas Leis no 13.860, de 29 de junho de 2004, e no 16.541, de 8 de setembro de 2016, fixando novos alinhamentos, nas Subprefeituras de Casa Verde/ Cachoeirinha e Mooca; altera dispositivos das Leis no 13.402, de 5 de agosto de 2002, no 15.360, de 14 de março de 2011, no 16.359, de 13 de janeiro de 2016, e no 16.050, de 31 de julho de 2014. Lei no 17.217, de 23 de outubro de 2019a.

SÃO PAULO (Município). Plano Diretor Estratégico, 5 anos da Lei no 16.050/2014. Cidade de São Paulo. Desenvolvimento urbano. Setembro, 2019b.

SÃO PAULO (Município). Secretaria Municipal de Urbanismo e Licenciamento de São Paulo. Ajustes da Lei 16.402/16. Minuta do Projeto de Lei. Justificativa Técnica, 2017.

SÃO PAULO (Município). Secretaria Municipal de Urbanismo e Licenciamento de São Paulo. Ajustes da Lei 16.402/16. Minuta do Projeto de Lei. Justificativa Técnica, 2017b. Available in: https://revisaolpuos.gestaourbana.prefeitura.sp.gov. br/. Access on: 29 jul. 2020.

SÃO PAULO (Município). Secretaria Municipal de Urbanismo e Licenciamento de São Paulo. Ata da Audiência Pública sobre a Minuta do Projeto de Ajustes na Lei de Parcelamento, Uso e Ocupação do Solo (Lei Municipal 16.402/2016), Zona Leste, realizada em 20 de fevereiro de 2018a.

SÃO PAULO (Município). Secretaria Municipal de Urbanismo e Licenciamento de São Paulo. Ata da Audiência Pública sobre a Minuta do Projeto de Ajustes na Lei de Parcelamento, Uso e Ocupação do Solo (Lei Municipal 16.402/2016), Zona Norte, realizada em 22 de fevereiro de $2018 \mathrm{~b}$.

SÃO PAULO (Município). Secretaria Municipal de Urbanismo e Licenciamento de São Paulo. 2a Minuta de projeto de lei, 2019a. Dispõe sobre ajustes e normas complementares à Lei 16.402, de 22 de março de 2016.

SÃO PAULO (Município). Secretaria Municipal de Urbanismo e Licenciamento de São Paulo. Ajustes da Lei 16.402/16. 2a Minuta do Projeto de Lei. Justificativa Técnica, 2019b. Available in: https://revisaolpuos.gestaourbana.prefeitura.sp.gov. br/. Access on: 30 jul. 2020.

SATTERTHWAIT, D. Climate change and urbanization: effects and implications for urban governance. United Nations expert group meeting on population distribution, urbanization, internal migration and development. New York: UN/POP/ EGMURB/2008/16, 2008.

SEPE, P. M.; PEREIRA, H. M. S. B. O conceito de Serviços Ambientais e o Novo Plano Diretor de São Paulo: uma nova abordagem para a gestão ambiental urbana? XVI ENANPUR, 2015. Anais [...], v. 16, n. 1, 2015.

SOMEKH, N.; MILITELLI, F. A questão ambiental e o mito da cidade compacta em São Paulo. In: JACOBI, P. R.; TORRES, P. H. C.; VENANCIO-FLORES, A. (Org). Dilemas ambiental-urbanos em duas metrópoles latino-americanas: São Paulo e Cidade do México no século XXI, 2021.

SOTTO, D. et al. Sustentabilidade urbana: dimensões conceituais e instrumentos legais de implementação. Estudos Avançados, São Paulo, v. 33, n. 97, p. 61-80, Dec. 2019.

TOMASIELLO, D. et al. Priorizar transporte público e priorizar o carro? Centro de Estudos da Metrópole, 12 de julho de 2021.

ULTRAMARI, C.; SILVA, R. C. E. O.; MEISTER, G. Idealizing Brazilian cities: their master plans from 1960 through, 2015. Cities, n. 83, p. 186-192, 2018.

VILLAÇA, F. J. M. As Ilusões do Plano Diretor, São Paulo, agosto de 2005.

WAMSLER, C. et al. Local levers for change: mainstreaming ecosystem-based adaptation into municipal planning to foster sustainability transitions. Global Environ. Change, v. 29, p. 189-201, 2014. 